\title{
Suboptimal Winter Chilling Impedes Development of Acrotony in Apple Shoots
}

\author{
Nigel C. Cook and Gerard Jacobs \\ Department of Horticultural Science, University of Stellenbosch, Private Bag \\ X1, Matieland 7602, South Africa
}

Additional index words. bud dormancy, branching dynamics, prolepsis, growth habit, Malus $\times$ domestica

\begin{abstract}
In 1997, 1-year-old, unbranched, $\approx 1-$-m-long shoots of the apple (Malus $\times$ domestica Borkh.) rootstock 'Merton-Immune 793' (MI.793) were selected at random from two commercial stoolbeds in the Western Cape, South Africa, during the dormant period. One site has mild winters [ 307 Utah Chill Units (CU) in $1997,34^{\circ} \mathrm{S}, 300 \mathrm{~m}$ ] while the other is moderately cold $\left(1497 \mathrm{CU}\right.$ in $\left.1997,3^{\circ} \mathrm{S}, 950 \mathrm{~m}\right)$. In 1998 , 'Granny Smith' shoots were collected from a mature orchard in another warm area $\left(574 \mathrm{CU}\right.$ in $\left.1998,34^{\circ} \mathrm{S}, 116 \mathrm{~m}\right)$. Shoots were prepared and forced at $25^{\circ} \mathrm{C}$ with continuous illumination. During dormancy the developmental rate was determined of the terminal bud, and of both distally and proximally situated lateral buds, with or without the inhibitory influence of a distal disbudded shoot piece $(10 \mathrm{~cm}$ long). In the moderately cold area, the growth rate of the terminal bud increased shortly before spring budburst such that a weak acrotonic tendency was established. The shorter dormant period, as experienced with the mild winters common to the apple-growing regions of the Western Cape, impeded the full development of acrotony and subsequent apical control. With less chilling (mild areas) a basitonic tendency remained. Budburst was slower and more erratic, and inhibition by the distal shoot parts was accentuated. Delayed foliation may be due more to correlative inhibition than to endodormancy. When lateral buds are released from paradormancy they exhibit a growth potential similar to, or, with less chilling, even greater than, that of the terminal bud. This permits a greater expression of autonomy between shoots.
\end{abstract}

Proleptic branching on apple shoots in spring is characterized by a dominance of the most distal buds, or acrotony (Rauh, 1939). In nonmanipulated apple trees, the pattern of budburst largely determines tree architecture, with acrotony a prerequisite for trunk formation (Champagnat, 1978; Crabbé, 1987). Winter chilling influences the intensity of bud dormancy and buds on the shoot axis respond differentially to modify the budburst pattern (Crabbé, 1994; Saure, 1985). Some have proposed that the intensity of dormancy of a bud can be perceived as a sum of inhibitions (Crabbé, 1994; Faust et al., 1997). In other words, the rate of budburst (under forcing conditions) is determined by the sum of the endodormant (endogenous to the bud) and paradormant (from organs and tissues outside the bud) components. The paradormant component largely includes inhibition by distal shoot tissues (Champagnat, 1983; Cook et al., 1998; Faust et al., 1995).

Under conditions of "complete chilling" in Belgium $\left(52^{\circ} \mathrm{N}\right)$, a clearly defined acrotonic tendency in budburst developed in shoots of

Received for publication 18 Dec. 1998. Accepted for publication 16 Mar. 1999. We are grateful to the Foundation for Research and Development, and the Deciduous Fruit Industry for financial support. The cost of publishing this paper was defrayed in part by the payment of page charges. Under postal regulations, this paper therefore must be hereby marked advertisement solely to indicate this fact. the apple rootstock 'Malling 9' (M.9) before budburst in spring (Cook et al., 1998). This "normal" tendency was established during an extended period of chilling (with increasing latitude, winters are characteristically colder and longer). In the absence of inhibition by distal shoot tissues, growth rate (1/days to $50 \%$ budburst) was much greater for the terminal bud (0.29) than for distal and proximal lateral buds ( 0.14 and 0.11 , respectively). With the strengthening of acrotony in late February, the terminal bud appears to exert a primigenic dominance (Bangerth, 1989) via an increased growth rate. Dominance was further accentuated by inhibition by the distal shoot tissues. As a result of a positional advantage, the terminal bud, in the absence of paradormant inhibitions, is capable of establishing dominance and, thus, a clearly defined acrotonic bud-bursting tendency.

Furthermore, opening of buds in similar positions on the different shoots was synchronized ( $<3 \mathrm{~d}$ under forcing conditions). Spring budburst on these shoots occurred first in the terminal bud, followed closely by numerous distally located laterals. The new terminal shoot rapidly established dominance or apical control (see Cline, 1997) over the proximally located laterals. Each subsequent lateral was inhibited sequentially in a proximal direction and the more proximal laterals were eventually reduced to spurs. Definition between the dominant leader and subordinate branches results via strong apical control. When numer- ous buds open and budburst is synchronized on a shoot axis, as occurs under conditions of superfluous chilling, correlative phenomena between buds appeared to be conducive to the development of stronger apical control (Cline, 1997; Cook et al., 1998; Crabbé, 1985).

A lack of adequate winter chilling greatly modifies the normal pattern of spring budburst, resulting in a phenomenon known as delayed foliation (Saure, 1985). Delayed foliation involves a prolonged period of opening of buds within and among shoots (Jacobs et al., 1981). Opening of the terminal bud following insufficient chilling is slower (Crabbé, 1994). This delay is further accentuated in the lateral buds, many of which remain dormant, resulting in the development of a reduced number of branches. Furthermore, an increased basitonic bursting tendency is observed, with the proximal lateral buds bursting more readily than the distal ones (Jacobs et al., 1981).

When trees are trained from unheaded whips in areas with insufficient chilling, an increased tendency towards basal dominance is observed, even with the use of rest-breaking chemicals (Cook and Strydom, 1998). The vigor or autonomy of individual, proximally situated branches is increased relative to that of the central axis (leader). Over time, the development of a dominant trunk is impeded. In the Koue Bokkeveld (near Ceres, $33^{\circ} \mathrm{S}, 950$ $\mathrm{m}$ ), winters are supposedly cold enough for "adequate" chilling [mean $\approx 1300$ Utah Chill Units (CU)]. However, budburst is less frequent and more erratic than is observed following artificial chilling (cold storage for 2-3 months at $4{ }^{\circ} \mathrm{C}$, personal observation). When trees are trained from unheaded whips, individual lateral shoots develop excessive vigor and compete with the leader during the growing season. Arguably, apical control is insufficient to contain the growth of all laterals as individual vigorous shoots develop autonomy. These autonomous shoots lead to basal dominance, a problem that intensifies with progressively less chilling (personal observation).

To develop a better understanding of the problem of delayed foliation on apple shoots, the roles of endodormancy and paradormancy were assessed under forcing conditions. We present data on the impeded development of acrotony in apple shoots growing under conditions of suboptimal winter chilling, making reference to previous observations of completely chilled apple shoots.

\section{Materials and Methods}

One-year-old, unbranched, $\approx 1$-m-long shoots of the apple rootstock MI.793 were selected randomly from two commercial stoolbeds in the Western Cape, South Africa, during Winter 1997. One site near Bonnievale $\left(34^{\circ} \mathrm{S}, 300 \mathrm{~m}\right)$ has warm winters, e.g., $307 \mathrm{CU}$ net for the months of May, June, July, and Aug. 1997. The other site, in the Koue Bokkeveld $\left(33^{\circ} \mathrm{S}, 950 \mathrm{~m}\right)$, is moderately cold, e.g., $1497 \mathrm{CU}$ for the same period. The net CU were calculated with chilling reversal factored in according to the model of Richardson et al. (1974). Shoots were harvested from the Koue 
Bokkeveld site on 2 May, 27 June, 1 Aug., and 22 Aug., and from the Bonnievale site on 29 May, 24 June, 1 Aug., and 25 Aug. The cessation of shoot elongation occurred earlier in the Koue Bokkeveld than at Bonnievale.

At each date, for both sites, 60 shoots were prepared for forcing (Fig. 1). All shoots were cut to a length of $80 \mathrm{~cm}$, discarding the basal portion, and then cut in half. For observations on the terminal buds (treatment T), from 20 shoots, the upper shoot halves (40 cm long) were bundled while the lower shoot halves were discarded. For the upper lateral bud, 20 upper shoot halves with the upper $10 \mathrm{~cm}$ removed (40 $\mathrm{cm}$ long, reduced to 30 ) were bundled (treatment UP-SH). A further 20 upper shoot halves with the upper $10 \mathrm{~cm}$ disbudded with a knife $(40 \mathrm{~cm}$ long with $10 \mathrm{~cm}$ disbudded) were bundled (treatment $\mathrm{UP}+\mathrm{SH}$ ). For observations on the lower lateral bud, 20 lower shoot halves with the upper $10 \mathrm{~cm}$ removed (40 cm long, reduced to 30 ) were bundled (treatment LO-SH). A further 20 lower shoot halves with the upper $10 \mathrm{~cm}$ disbudded $(40 \mathrm{~cm}$ long with $10 \mathrm{~cm}$ disbudded) were bundled (treatment $\mathrm{LO}+\mathrm{SH}$ ).

At each date, the bundles were placed in 5$\mathrm{L}$ white plastic buckets (three to four bundles per bucket), with their bases in $\approx 1 \mathrm{~L}$ of water containing $5 \mathrm{~mL} \cdot \mathrm{L}^{-1}$ household bleach $(5 \%$ sodium hypochlorite). The buckets containing the bundled shoot segments were placed in a growth chamber that maintained a constant $25{ }^{\circ} \mathrm{C}$ with continuous illumination $(215$ $\mu \mathrm{mol} \cdot \mathrm{m}^{-2} \cdot \mathrm{s}^{-1}$ photosynthetically active radia- tion). The water was replaced every 2 to $3 \mathrm{~d}$.

The number of shoot segments with buds that reached green tip was recorded for each bundle every 2 to $3 \mathrm{~d}$ until budburst was observed on a minimum of 10 segments per bundle. Occasionally, bundles did not attain the minimum of 10 segments with burst buds. As a result, the time was recorded when budburst was observed on five segments per bundle ( $25 \%$ budburst). The data are presented as the rate of bud development (Cannell, 1989), e.g., $1 /$ (days to $25 \%$ budburst), for each respective bundle.

In 1998, a similar trial was conducted on 'Granny Smith'. Shoots $\approx 90 \mathrm{~cm}$ long were selected randomly from mature trees in an orchard in Stellenbosch (574 CU net for May, June, July, and Aug. 1998 , $\left.34^{\circ} \mathrm{S}, 116 \mathrm{~m}\right)$. On 22 June, 21 July, 18 Aug., and 15 Sept., 40 shoots were harvested and cut into three 30 $\mathrm{cm}$ segments, discarding the basal portion. Buds were removed from the upper $10 \mathrm{~cm}$ (30 $\mathrm{cm}$ long with $10 \mathrm{~cm}$ disbudded) of the middle and lower segments of 20 shoots $(+\mathrm{SH})$. On the remaining 20 shoots the upper $10 \mathrm{~cm}$ section was removed $(30 \mathrm{~cm}$ long, reduced to $20)$ from the middle and lower segments $(-\mathrm{SH})$. Both groups of 20 terminal segments (T) received no further treatment. The $20 \mathrm{seg}$ ments of each treatment were bundled and forced, and the rate of bud development was recorded as in 1997. Growth rate was thus determined for the terminal bud ( $\mathrm{T})$, a lateral bud situated $40 \mathrm{~cm}$ from the apex (M), and a lateral bud situated $70 \mathrm{~cm}$ from the apex (LO).

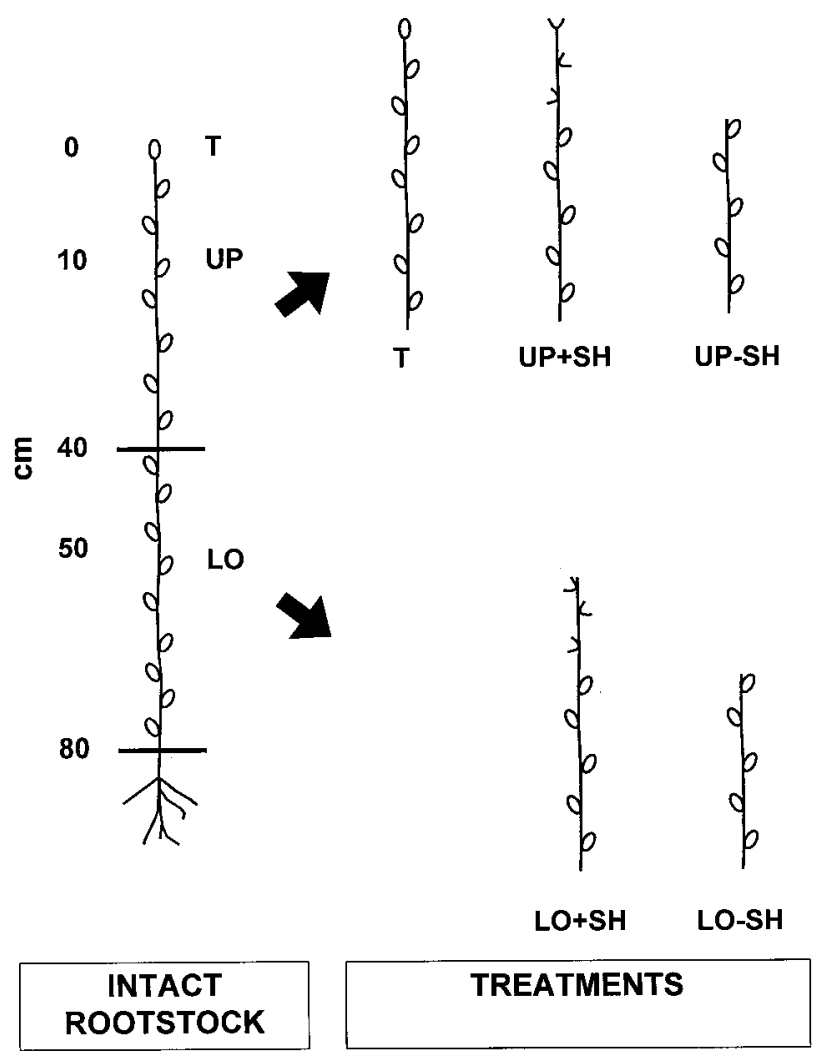

Fig. 1. Diagrammatic representation of the treatments used on MI.793 apple shoots in 1997. (T) terminal bud; (UP) upper lateral bud; (LO) lower lateral bud; $(+\mathrm{SH})$ and $(-\mathrm{SH})$ presence or absence of a 10-cm-long disbudded shoot piece distal to bud.

\section{Results and Discussion}

Budburst always occurred in the most distal one or two buds, with the more proximal buds remaining inhibited (paradormant). Endodormancy was estimated as growth rate of buds under forcing conditions with the distal stem tissues removed. The sum of endodormancy and paradormancy was estimated as the growth rate of buds including the inhibition of $10 \mathrm{~cm}$ of distal stem tissues (buds removed). In intact shoots paradormancy is assumed to be greater than our estimation. Bud growth rate (compared with days to budburst) permits easy comparison of the relative development of buds in different positions, especially when development is more rapid in spring (Cannell, 1989; Cook et al., 1998).

In the moderately cold Koue Bokkeveld (1497 CU), the progression of endodormancy in buds on shoots of the rootstock MI.793 was similar to that observed in shoots of the rootstock M.9 growing in Belgium (Cook et al., 1998). A basitonic tendency was observed in the autumn and early winter that changed to an acrotonic tendency as spring approached $(-\mathrm{SH}$, Table 1). A distinct change was evident in the growth rate of the terminal bud after 27 June, as it rapidly increased relative to the growth rates of the upper and the lower lateral buds. By 22 Aug. an acrotonic tendency was observed. With distal stem tissue (paradormancy), the acrotonic tendency was accentuated $(+\mathrm{SH}$, Table 1).

The acrotonic tendency that developed in MI.793 shoots in the Koue Bokkeveld, without paradormancy $(-\mathrm{SH})$, was not as clearly defined as in M.9 shoots in Belgium. While temperatures in the Koue Bokkeveld are sufficiently cold for an apparently normal initial development of dormancy in the buds, the winter is too short for the development of the clearly defined acrotonic tendency and subsequent apical control observed with more chilling. In the Koue Bokkeveld, the acrotonic development of shoots still occurs in intact whip trees without manipulation; however, reduced apical control of the terminal over laterals complicates management (personal observation). As indicated in these data for buds with distal stem tissue (+SH, Table 1$)$, acrotony is accentuated by the correlative inhibition of the lateral buds by the distal tissues.

By contrast, on shoots grown in the mild Bonnievale area (307 CU) without distal stem tissue $(-\mathrm{SH})$, a basitonic tendency was observed throughout the winter (Table 1). On 29 May (autumn), terminal buds burst poorly $(<25 \%)$. Thereafter, the terminal bud growth rate remained low and did not increase relative to the lateral buds, as occurred in colder climates. The progression of endodormancy in the lateral buds $(-\mathrm{SH})$ appeared more normal; growth rate decreased until late winter, then increased. Distal stem tissue $(+\mathrm{SH})$ reduced the growth rate of lateral buds; by 25 Aug., the growth rates of the terminal and lower lateral buds were similar (0.03), but that of the upper lateral bud was greatly diminished $(<25 \%$ budburst). In this assessment of "total" dormancy in MI.793 shoots growing in a mild 
winter climate, the growth rate just before spring is comparable to that of buds in deep dormancy.

On similarly treated 'Granny Smith' shoots grown in Stellenbosch (574 CU), budburst remained basitonic with the terminal buds showing poor growth potential (Table 2). While the inhibition by distal stem tissues $(+\mathrm{SH})$ increased toward spring, the growth rate of more proximal lateral buds was greater than in MI.793.

The presence of distal stem tissue $(+\mathrm{SH})$ reduced the rate of lateral budburst (Tables 1 and 2). In M.9 in Belgium, the inhibition remained more or less constant (Cook et al. 1998). Locally, the inhibition generally increased with the approach of spring in certain positions. In shoots grown in the Koue Bokkeveld, the inhibition was more pronounced in the lower than in the upper lateral buds. In shoots grown at Bonnievale, the reverse was true. While no upper lateral bud was observed on the shoots collected from Stellenbosch, the more proximal laterals behaved in a manner similar to those on MI.793 shoots from Bonnievale. This increased bursting potential of lower lateral buds has been reported previously for insufficiently chilled 'Golden Delicious' shoots (Jacobs et al., 1981).

An increase in the inhibitory capacity of a distal shoot piece may be a characteristic of suboptimal chilling. The inhibition is probably the result of polar auxin transport, which can be eliminated by girdling or notching (Champagnat, 1983), a practice that is commonly used locally with great success (Cook and Strydom, 1998). Furthermore, polar auxin transport stops at low temperatures $\left(2\right.$ to $7^{\circ} \mathrm{C}$ ) (Morris, 1979), and during endodormancy in cold climates (Hollis and Tepper, 1971). Locally, under the warm winter conditions, auxin transport may continue, resulting in an enhanced distal inhibition during dormancy. The cambium may play a more important role in bud dormancy than has previously been suggested (Saure, 1985). Faust et al. (1995) also discuss the inhibition of lateral buds by the terminal bud, i.e., apical dominance effects, during dormancy.

As was observed with M.9 in Belgium, our data show a trend, at lower developmental rates (deeper dormancy), of protracted budburst in comparable positions on different shoots (Tables 3 and 4). As spring approached, budburst became more synchronized among shoots. By the end of the dormancy at all sites, budburst among shoots was less synchronized than was observed on M.9 shoots at the end of the dormant period in Belgium ( $<3 \mathrm{~d})$ (Cook et al., 1998).

When trees are grown from nonheaded whips in South Africa, even in the Koue Bokkeveld, budburst is more erratic, not only among buds on the same shoot, but also especially among trees on the same site (Cook and Strydom, 1998). This erratic budburst pattern complicates the execution of treatments (e.g., notching), required to establish successful highdensity apple plantings under South African conditions. Erratic bursting of fewer buds reduces apical control and permits a greater
Table 1. Changes during winter in developmental rate (1/days to $25 \%$ budburst) of buds in different positions along 1-year-old MI.793 apple shoots under forcing conditions. The shoots were collected in 1997 from commercial stoolbeds growing in the moderately cold Koue Bokkeveld [1497 Utah Chill Units (CU)] and the mild Bonnievale (307 CU), S. Africa.

\begin{tabular}{lcccccc}
\hline \hline Source & Bud & Shoot $^{2}$ & \multicolumn{4}{c}{ Date of collection } \\
\hline Koue Bokkeveld & & & $\underline{2 \text { May }}$ & $\frac{27 \text { June }}{1 \text { Aug. }}$ & $\underline{22 ~ A u g}$. \\
& $\mathrm{T}^{\mathrm{y}}$ & & 0.06 & 0.02 & 0.06 & 0.08 \\
& $\mathrm{UP}^{\mathrm{x}}$ & - & 0.06 & 0.04 & 0.07 & 0.06 \\
& & + & 0.06 & 0.04 & 0.04 & 0.04 \\
Bonnievale & LO $^{\mathrm{w}}$ & - & 0.08 & 0.06 & 0.06 & 0.06 \\
& & + & 0.06 & 0.03 & 0.04 & 0 \\
& $\mathrm{~T}$ & & $\underline{29 \mathrm{May}}$ & $\underline{24 \mathrm{June}}$ & $\underline{1 \text { Aug. }}$ & $\underline{25 \mathrm{Aug} .}$ \\
& $\mathrm{UP}$ & - & 0.07 & 0.04 & 0.03 & 0.03 \\
& & + & 0.02 & 0.05 & 0.04 & 0.07 \\
& $\mathrm{LO}$ & - & 0.09 & 0.06 & 0.05 & 0.07 \\
& & + & 0.09 & 0.05 & 0.02 & 0.03 \\
\hline
\end{tabular}

${ }^{2}$ Portion of shoot distal to bud removed (-shoot) or disbudded (+shoot).

yTerminal bud.

${ }^{x}$ Upper lateral bud $10 \mathrm{~cm}$ from apex.

${ }^{w}$ Lower lateral bud $50 \mathrm{~cm}$ from apex.

Table 2. Changes during winter in developmental rate (1/days to $25 \%$ budburst) of buds in different positions along 1-year-old 'Granny Smith' apple shoots under forcing conditions. The shoots were collected in 1998 from mature trees growing in Stellenbosch (574 CU), S. Africa.

\begin{tabular}{lccccc}
\hline \hline & & \multicolumn{3}{c}{ Date } \\
\cline { 3 - 6 } Bud & Shoot $^{\mathrm{z}}$ & 2 May & 27 June & 1 Aug. & 22 Aug. \\
\hline $\mathrm{T}^{\mathrm{y}}$ & & 0.03 & 0 & 0.02 & 0 \\
$\mathrm{M}^{\mathrm{x}}$ & - & 0.08 & 0.06 & 0.07 & 0.21 \\
& + & 0.07 & 0.06 & 0.05 & 0.14 \\
LO $^{\mathrm{w}}$ & - & 0.07 & 0.07 & 0.06 & 0.20 \\
& + & 0.04 & 0.05 & 0.05 & 0.14 \\
\hline
\end{tabular}

${ }^{2}$ Portion of shoot distal to bud removed (-shoot) or disbudded (+shoot).

${ }^{y}$ Mean of both bundles of terminal shoot segments presented.

${ }^{x}$ Middle lateral bud $40 \mathrm{~cm}$ from apex.

${ }^{w}$ Lower lateral bud $70 \mathrm{~cm}$ from apex.

Table 3. The time (d) from when budburst was observed in the first MI.793 apple shoot to when it was observed in the fifth shoot (25\% budburst) in each bundle of 20 shoot segments (treatment), Winter 1997. Shoots sampled from two locations, Koue Bokkeveld (1497 CU) and Bonnievale (307 CU), S. Africa.

\begin{tabular}{|c|c|c|c|c|c|}
\hline \multirow[b]{3}{*}{ Date of collection } & \multicolumn{5}{|c|}{ Bud position } \\
\hline & \multirow[b]{2}{*}{ Terminal } & \multicolumn{2}{|c|}{$\begin{array}{c}\text { Upper lateral }^{\mathrm{z}} \\
\end{array}$} & \multicolumn{2}{|c|}{ Lower lateral $^{\mathrm{y}}$} \\
\hline & & $-\operatorname{shoot}^{\mathrm{x}}$ & $+\operatorname{shoot}^{x}$ & - shoot & + shoot \\
\hline \multicolumn{6}{|c|}{ Koue Bokkeveld (cool) } \\
\hline 2 May & $<1$ & 4 & 5 & 2 & 2 \\
\hline 27 June & 15 & 6 & 9 & 8 & 16 \\
\hline 1 Aug. & 7 & 5 & 2 & 1 & 6 \\
\hline 22 Aug. & 6 & 2 & 18 & 7 & $>66$ \\
\hline \multicolumn{6}{|c|}{ Bonnievale (mild) } \\
\hline 29 May & $>66$ & 4 & 29 & $<1$ & $<1$ \\
\hline 24 June & 5 & 11 & 4 & 3 & 7 \\
\hline 1 Aug. & 11 & 10 & 27 & 2 & 8 \\
\hline 25 Aug. & 10 & 1 & $>66$ & 2 & 3 \\
\hline
\end{tabular}

${ }^{2}$ Upper lateral bud $10 \mathrm{~cm}$ from apex.

'Lower lateral bud $50 \mathrm{~cm}$ from apex.

xPortion of shoot distal to bud removed (-shoot) or disbudded (+shoot).

Table 4. The time (d) from when budburst was observed in the first 'Granny Smith' apple shoot to when it was observed in the fifth shoot ( $25 \%$ budburst) in each bundle of 20 shoot segments (treatment), Winter 1998. Shoots sampled in Stellenbosch (574 CU), S. Africa.

\begin{tabular}{|c|c|c|c|c|c|}
\hline \multirow[b]{3}{*}{ Date of collection } & \multicolumn{5}{|c|}{ Bud position } \\
\hline & \multirow[b]{2}{*}{ Terminal $^{\mathrm{z}}$} & \multicolumn{2}{|c|}{ Middle lateral $^{\mathrm{y}}$} & \multicolumn{2}{|c|}{ Lower lateral $^{\mathrm{x}}$} \\
\hline & & - shoot $^{\mathrm{w}}$ & $+\operatorname{shoot}^{\mathrm{w}}$ & -shoot & + +shoot \\
\hline 2 May & 25 & 2 & 5 & $<1$ & $<1$ \\
\hline 27 June & $>45$ & 6 & 4 & 1 & 6 \\
\hline 1 Aug. & 27 & 4 & 4 & 3 & 6 \\
\hline 22 Aug. & $>45$ & 4 & 1 & 4 & $<1$ \\
\hline
\end{tabular}

${ }^{2}$ Mean of both bundles of terminal shoot segments presented.

yMiddle lateral bud $40 \mathrm{~cm}$ from apex.

${ }^{x}$ Lower lateral bud $70 \mathrm{~cm}$ from apex.

wPortion of shoot distal to bud removed (-shoot) or disbudded (+shoot). 
expression of shoot autonomy, which, even in the Koue Bokkeveld, requires bending in the growing season to manage the excessively vigorous lateral shoots. An extended cold period appears to be necessary for the restoration of growth rate and the synchronization of budburst, and these aspects of budburst may be necessary for the development of apical control of the distal shoot, a prerequisite for acrotonic branching.

Manipulations that release lateral buds from paradormancy, e.g., notching, allow buds to develop at the growth potential that is inherent to the bud. In these data, the growth rate of lateral buds without distal inhibitions $(-\mathrm{SH})$ was considerably greater than that of buds with them $(+\mathrm{SH})$. In insufficiently chilled shoots from Bonnievale and Stellenbosch, the inherent growth potential of the lateral buds $(-\mathrm{SH})$ was greater than that of the terminal bud. Lateral buds on insufficiently chilled shoots that are released from paradormancy by notching will have a developmental advantage relative to the terminal bud. Even though a leader usually develops, the reduced growth potential of the terminal bud (increased endodormancy) at the time of budburst may reduce the capacity of the new leader to exert sufficient apical control over lateral shoots. These laterals develop autonomy and result in basal dominance. This response is commonly observed when training trees from nonheaded whips in these regions (Cook and Strydom, 1998). However, following artificial chilling of nursery trees in cold rooms $\left(4^{\circ} \mathrm{C}\right)$, apical control is maintained and a more "normal" acrotonically branched architecture develops (Cook and Strydom, 1998). With subsequent manipulation, branches can readily be trained to an overall conical form ideal for highdensity plantings.

In conclusion, the lack of an extended dormant period associated with the mild winters common to the apple-growing regions of the Western Cape impedes the development of acrotony. This appears to be due, in part, to an inherent low growth rate of the buds (increased endodormancy), and less synchronization among buds at the time of spring budburst, resulting in both a delayed and more erratic budburst. Furthermore, a considerably increased paradormant inhibition by the distal shoot parts is observed. Paradormancy largely accounts for the inhibition of budburst of the upper lateral buds under conditions of suboptimal chilling. The causes of delayed foliation may reside more in the shoot piece than in the buds themselves.

\section{Literature Cited}

Bangerth, F. 1989. Dominance among fruits/sinks and the search for a correlative signal. Physiol. Plant. 76:608-614.

Cannell, M.G.R. 1989. Chilling, thermal time, and the date of flowering of trees, p. 99-113. In: C.J. Wright (ed.). Manipulation of fruiting. Butterworths, London.

Champagnat, P. 1978. Formation of the trunk in woody plants, p. 401-422. In: P.B. Tomlinson and M.H. Zimmermann (eds.). Tropical trees as living systems. Cambridge Univ. Press, Cambridge, U.K.

Champagnat, P. 1983. Bud dormancy, correlation between organs, and morphogenesis in woody plants. Soviet Plant Physiol. 30:458-471.

Cline, M.G. 1997. Concepts and terminology of apical dominance. Amer. J. Bot. 84:1064-1069.

Cook, N.C., E. Rabe, J. Keulemans, and G. Jacobs. 1998. The expression of acrotony in deciduous fruit trees: A study of the apple rootstock M.9. J. Amer. Soc. Hort. Sci. 123:30-34.

Cook N.C. and D.K. Strydom. 1998. The South African high density system. Acta Hort. (In press.)

Crabbé, J.J. 1985. Aspects of the apical control on branching in one-year-old caulinary axes of woody plants. Acta Univ. Agri. 33:555-559.

Crabbé, J. 1987. Aspects particuliers de la morphogenése caulinaire des végétaux ligneux et introduction à leur étude quantitative. Centre d'Etude de la Reproduction Vég., Brussels.

Crabbé, J. 1994. Dormancy, p. 597-611. In: C.J. Arntzen and E.M. Ritter (eds.). Encyclopedia of agricultural science, Vol. 1. Academic, New York.

Faust, M., A. Erez, L.J. Rowland, S.Y. Wang, and H.A. Norman. 1997. Bud dormancy in perennial fruit trees: Physiological basis for dormancy induction, maintenance, and release. HortScience 32:623-629.

Faust, M., D. Liu, S.Y. Wang, and G.W. Stutte. 1995 Involvement of apical dominance in winter dormancy of apple buds. Acta Hort. 395:47-56.

Hollis, C.A. and H.B. Tepper. 1971. Auxin transport within intact dormant and active white ash shoots. Plant Physiol. 48:146-149.

Jacobs, G., P.J. Watermeyer, and D.K. Strydom. 1981. Aspects of winter rest of apple trees. Crop Prod. 10:103-104.

Morris, D.A. 1979. The effect of temperature on the velocity of exogenous auxin transport in intact chilling-sensitive and chilling-resistant plants. Planta 146:603-605.

Rauh, W. 1939. Über Gesetzmäßigkeit der Verweigung und deren Bedeutung für die Wuchsformen der Pflanzen. Mitt. Dtsch. Dendr. Ges. 52:86-111

Richardson, E.A., S.D. Seeley, and D.R. Walker. 1974. A model for estimating the completion of rest for 'Redhaven' and 'Elberta' peach trees. HortScience 9:331-332.

Saure, M.C. 1985. Dormancy release in deciduous fruit trees. Hort. Rev. 7:239-300. 